\title{
Příspěvek k teorii a dějinám střední evropy
}

\author{
Miloš Zelenka
}

Střední Evropa včera a dnes: proměny koncepcí. Kolektivní monografie. Ed. Ivo Pospišil. Brno: Jan Sojnek nakladatelství Galium, 2015. 616 s. ISBN 978-80-965336-7-7.

Téma střední Evropy přestalo být výlučnou záležitostí politiků či politologů nebo historiků připomínajících stabilitu i chaos tohoto proměnlivého, kulturně-geografického areálu, který se brání striktnímu zeměpisnému určení. Fenomén střední Evropy ve své heterogenitě se proto stále častěji stává intelektuálním konstruktem směřujícím k umění, ke kultuře, ale i k sociologii, filosofii, sémiotice a také k literární vědě. Do tohoto akademického prostoru úspěšně vstupuje kolektivní monografie Středni Europa včera a dnes: proměny koncepcí, která navazuje na dlouholetou tradici slavistického zkoumání střední Evropy jako umělecké a myšlenkové křižovatky mezi Západem a Východem, na tradici analyzující způsoby vzájemné komunikace, střety a konflikty poetik. Lze tu připomenout zejména práce brněnské morfologické školy vyrůstající z koncepce filologicko-areálového bádání, četné publikace iniciované Ústavem slavistiky na FF MU v Brně a Středoevropským centrem slovanských studií, konkrétně sborník Comparative Cultural Studies in Central Europe (eds. I. Pospíśil - M. Moser, 2004), dále monografii I. Pospísila Středni Evropa a Slované (2006), která personalisticky ukázala, že střední Evropa se v současnosti stává citlivým ukazatelem nejen celoevropských změn a geopolitických posunů, ale i synonymickou formou hledání regionální, resp. národní identity.

Kolektivní monografie, kterou zahajuje úvodní stat editora Stredni Evropa: posuny důrazů (s. 9-15), k níž je připojena výběrová bibliografie $\mathrm{k}$ areálovým středoevropským studiím, celkově obsahuje 63 texty od badatelů ze 7 zemí (Česká republika, Francie, Německo, Polsko, Slovensko, Slovinsko a Ukrajina). Ty byly většinou předneseny na konferenci o střední Evropě ve dnech 18.-19. 11. 2014 v Brně organizované Středoevropským centrem slovanských studií ve spolupráci s Českou asociací slavistů, Slavistickou společností Franka Wollmana a Ústavem slavistiky FF MU v Brně. Jestliže Pospíšil v úvodní studii nastiňuje sémantické a strukturální proměny ve výzkumu střední Evropy jako jistého „mostu“ a rozporuplného „jádra“ celé Evropy, ostatní příspěvky, které se kompozičně člení na dvě základní části: Filologicko-areálová studia a Historie a kulturologie, tematicky pokrývají širokou oblast od filologie až po politologii a sociální vědy, přičemž za spojovací rys zde lze považovat komplementární prostupování rozmanitých politických a kulturních kontextů, v kterých je možné tento fenomén historicky a aplikačně analyzovat. Zatímco první oddíl referátů se zaměřil na zkoumání tzv. středoevropského fenoménu v literatuře a jazyce, druhý blok interdisciplinárně laděných textů směřoval k pochopení a objasnění metodologických koncepcí střední Evropy realizovaných převážně v 19. a 20. století. K hlavním badatelským okruhům patřila témata jako existence středoevropských literatur, střední Evropa jako duchovní element a kulturně-geografický areál, etnicko-jazykový obraz střední Evropy, její bilingvismus a biliterárnost, úloha židovského aspektu, střediska výzkumu o střední Evropě, proměnlivost centra a periférie, střední Evropa a V4, resp. Evropská unie, vztah střední Evropy k Západu a Východu, metodologické koncepce střední Evropy v minulosti a současnosti, střední Evropa v kontextu Uher a Balkánu, středoevropskost a středoevropanství jako integrační a disimilační faktor, problematika emigrace, toposy a symbolika střední Evropy, „habsburská“ střední Evropa, „středoevropské“ umělecké a literární žánry. 
Je nesporné, že brněnská publikace se v záplavě četné odborné domácí i překladové literatury o střední Evropě zařadí k trvalým hodnotám, které obohatí v historiografickém pohledu poznání tohoto kulturně-geografického fenoménu o nové aspekty. Sympatická je zde snaha na rozdíl od sborníkové antologie $V$ kleštich dějin. Středni Evropa jako pojem a problém (2009) vyvarovat se módnosti a senzačnosti tématu: být, jak zdůrazňuje editor I. Pospíšil, „střizlivým pracouním pohledem“ (s. 13), který při- náší relevantní informace, interpretace a shrnutí, tj. sumarizaci a revizi dosavadního stavu komplexního bádání o střední Evropě. Ačkoli tato rozsáhlá kolektivní monografie se jistě stane předmětem dalšího metakritického diskursu, akcent na komparativní, personalistický a interdisciplinární přístup $\mathrm{v}$ historické i synchronní dimenzi činí z této publikace ve svém souhrnu z jednotlivých „hlasů“ modelovou reflexi, kterou nebude možné při dalším studiu střední Evropy pominout. 